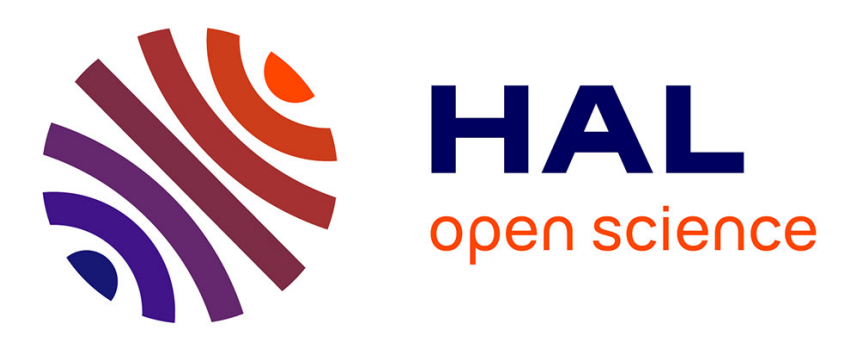

\title{
A new rhinoceros clade from the Pleistocene of Asia sheds light on mammal dispersals to the Philippines
}

Pierre-Olivier Antoine, Marian C Reyes, Noel Amano, Angel P Bautista, Chun-Hsiang Chang, Julien Claude, John de Vos, Thomas Ingicco

\section{- To cite this version:}

Pierre-Olivier Antoine, Marian C Reyes, Noel Amano, Angel P Bautista, Chun-Hsiang Chang, et al.. A new rhinoceros clade from the Pleistocene of Asia sheds light on mammal dispersals to the Philippines. Zoological Journal of the Linnean Society, 2021, 10.1093/zoolinnean/zlab009 . hal-03450400

\section{HAL Id: hal-03450400 \\ https://hal.umontpellier.fr/hal-03450400}

Submitted on 26 Nov 2021

HAL is a multi-disciplinary open access archive for the deposit and dissemination of scientific research documents, whether they are published or not. The documents may come from teaching and research institutions in France or abroad, or from public or private research centers.
L'archive ouverte pluridisciplinaire HAL, est destinée au dépôt et à la diffusion de documents scientifiques de niveau recherche, publiés ou non, émanant des établissements d'enseignement et de recherche français ou étrangers, des laboratoires publics ou privés. 
Biological Sciences/Evolution

Original Article

A new rhinoceros clade from the Pleistocene of Asia sheds light on mammal dispersals to the Philippines

Pierre-Olivier Antoine ${ }^{1 *}$, Marian C. Reyes ${ }^{2}$, Noel Amano ${ }^{3}$, Angel P. Bautista ${ }^{4}$, Chun-Hsiang Chang $^{5}$, Julien Claude ${ }^{1}$, John de Vos $^{6}$, Thomas Ingicco ${ }^{7}$

${ }^{1}$ Institut des Sciences de l'Évolution de Montpellier, Université de Montpellier, CNRS, IRD, EPHE, Place Eugène Bataillon, 34095 Montpellier Cedex 05, France, pierre-olivier.antoine@umontpellier.fr, julien.claude@umontpellier.fr

${ }^{2}$ Archaeology Division, National Museum of the Philippines, P. Burgos Drive, Rizal Park, Manila, Philippines, mariancreyes@gmail.com

${ }^{3}$ Department of Archaeology, Max Planck Institute for the Science of Human History, Kahlaische Str. 10, 07745 Jena, Germany, amano@shh.mpg.de

${ }^{4}$ Cultural Properties Division, National Museum of the Philippines, P. Burgos Drive, Rizal Park, Manila, Philippines, angelparana52@yahoo.com

${ }^{5}$ Department of Geology, National Museum of Natural Science, Taiwan, chang28@gmail.com

${ }^{6}$ Naturalis Biodiversity Center, P.O. Box 9517, 2300 RA Leiden, The Netherlands, john.devos@naturalis.nl

${ }^{7}$ Histoire naturelle de l'Homme préhistorique, Département Homme et Environnement, Muséum National d'Histoire Naturelle, Université de Perpignan Via Domitia, Centre National de la Recherche Scientifique (UMR7194), Institut de Paléontologie Humaine 1, rue René Panhard 75013 Paris, France, ingicco@mnhn.fr

*Corresponding author

Running title A Pleistocene rhinoceros from Asia

\section{Abstract}

Rhinoceroses are among the most endangered mammalian species today. Their past diversity is well documented from the Eocene onward, although their evolutionary history is far from being fully understood. Here, we elucidate the systematic affinities of a Pleistocene rhinoceros species represented by a partial skeleton from $709 \pm 68$ ka archaeological deposits in Luzon Island, Philippines. We perform a comprehensive phylogenetic analysis including all living species and a wide array of extinct rhinocerotid species. We confirm the early split between Elasmotheriinae and Rhinocerotinae at c $35.5 \mathrm{Ma}$ and constrain the divergence between recent Asian and African rhinoceroses at c $24 \mathrm{Ma}$, with contrasting phenotypic evolutionary rates in Diceroti and Rhinoceroti. Dental features reveal the existence of an unsuspected Asian Pleistocene clade, referred to as Nesorhinus gen. nov. It includes the 
rhinoceros from the Philippines and another extinct species from Taiwan, N. hayasakai. Nesorhinus is sister group to a cluster comprising Dicerorhinus and Rhinoceros. Our phylogenetic results strongly suggest an island-hopping dispersal for Nesorhinus, from Asian mainland towards Luzon via Taiwan by late Miocene times or later, and Pleistocene dispersals for representatives of Rhinoceros. Nesorhinus philippinensis would be the first perissodactyl species supporting the island-rule hypothesis, with decreased body weight and limb-bone robustness.

ADDITIONAL KEYWORDS: Island biogeography - island fauna - evolutionary trends morphological phylogenetics - morphological systematics - Mammalia

\section{INTRODUCTION}

Past dispersal patterns of terrestrial vertebrates towards and within the Philippine archipelago remain a widely debated topic. As none of these islands has ever been connected to mainland Southeast Asia, even during the most severe Pleistocene sea level drops (Past Interglacials Working Group of PAGES, 2016), the question of ancient island hopping is still controversial (Braches \& Shutler, 1984; Heaney, 1985; Bellwood, 2013; Morwood, 2014; Suraprasit et al., 2016). Historically, three major Pleistocene dispersal routes to the islands of Southeast Asia have been considered: one along the exposed Sunda Shelf from the Siwaliks during the Early-Middle Pleistocene with extinct genera like Stegodon (the Siva-Malayan route), a second from China via Thailand to Indonesia with extant genera like Pongo in the Late Pleistocene (the Sino-Malayan route) and the third across sea barriers from Taiwan to the Philippines and elsewhere to the South and to the West. This latter hypothesis was favoured as the main route to the Wallacean islands by von Koenigswald (1956) while other scholars preferred the Sino-Malayan route with Palawan Island as the main gate to the Philippines (de Terra et al., 1941; Grooves, 2001). Hooijer $(1951,1958)$ suggested that the two routes might have acted together but not necessarily at the same time.

Recent phylogenetic studies have investigated (pre-)Pleistocene dispersals of modern land vertebrates to the pristine Philippine Islands, by a time the archipelago had not acquired its present shape and configuration yet (Brown et al., 2013 and references therein). While some clades of frogs (Blackburn et al., 2010) or geckos (Siler et al., 2012) have benefited from the drifting of Palawan terrane from the South China's coast to its present position, other clades of amphibians (Brown \& Guttman, 2002; Evans et al., 2003) and birds (Jones \& Kennedy, 2008) have probably migrated from the Sunda shelf fringe, either on the north from Borneo to Palawan and Mindoro or on the south via Sulu for some others (Jones \& Kennedy, 2008). Among the four hypothetical gateways to the Philippines (Dickerson, 1928; Brown et al., 2003), the northern route from Taiwan to Luzon seems for the moment to have only been active for shrews (Esselstyn \& Oliveros, 2010). Interestingly, phylogeography of termites evidences a successful West-East rafting dispersion over the South China Sea from Thailand and through Vietnam to the Philippines between 1.09 and $0.42 \mathrm{Ma}$ (Singham et al., 2017). These studies are generally underestimating the potential contribution of Pleistocene (and pre-Pleistocene) dispersals to the modern biodiversity of Island Southeast Asia. The scarcity of the fossil remains on those oceanic islands can be a reason for this. In the vicinity of Metro Manila, geologists from the National Institute of Geological Sciences reported, in 
collaboration with German palaeontologists, on the recovery of giant land tortoise they named Manouria sondaari (Karl \& Staesche, 2007; Rhodin et al., 2015). Rhodin et al. (2015) nevertheless reattributed these fossils to Megalochelys sondaari. So far, this uncertainty regarding its systematics, which is most certainly related to its fragmentary preservation, prevents any phylogenetic interpretation. Von Koenigswald (1956) described the elephantoid Stegodon luzonensis based on a fragment of a mandible containing a broken last molar found within the Guadalupe tuff covering the Manila Basin area and given to him by the archaeologist $\mathrm{H}$. Otley Beyer. This species is better described by additional surfacecollected specimens by de Vos \& Bautista (2001). The few measurable teeth at hand of this endemic taxon to the Philippines are smaller than the Javanese species $S$. trigonocephalus and the Chinese S. orientalis (de Vos \& Bautista, 2001: 6-7). De Vos \& Bautista (2001) add that the M3 of $S$. luzonensis is rather small, although it is larger than the ones of the dwarf $S$. sompoensis from Sulawesi, the small S. sondaari from Flores, and S. timorensis from East Timor. This combination of unique dimensional features and the limited number of wellpreserved fossils makes difficult to link S. luzonensis to any other taxa at the moment. At last, Ingicco et al. (2017) noted the presence of the extinct suid Celebochoerus on Luzon Island, only known elsewhere on the southern island of Sulawesi although in a different form, suggesting a possible faunal exchange between those two islands but without being capable of knowing towards which direction.

A partial skeleton of Rhinoceros philippinensis von Koenigswald, 1956 (Figure S1) was recently discovered at Kalinga site in Northern Luzon from a $709 \pm 68$ ka archaeological layer. Stone tools were recovered together with the skeleton and several skeletal elements exhibited evidence of butchery (Ingicco et al., 2018, 2020). This early Middle Pleistocene individual considerably adds to the knowledge of Philippine rhinocerotid species, as its hypodigm was restricted to a few fossil teeth without any clear stratigraphic context, recovered from different islands in the archipelago (von Koenigswald, 1956; Bautista, 1995). The completeness of the specimen allows us to test the different phylogenetic and subsequently palaeobiogeographical scenarios at hand.

In order to constrain the taxonomical assignment and phylogenetic affinities of $R$. philippinensis and then to test potential dispersal pathways of rhinos toward the Philippine archipelago, a broad morpho-anatomical comparison was undertaken within Rhinocerotidae and a parsimony analysis was performed, allowing for discussing further the systematics and biogeographical history of rhinocerotines.

\section{MATERIAL AND METHODS}

Phylogenetic relationships were retrieved using a data matrix implemented from a proven matrix focusing on Rhinocerotidae (Antoine, 2002; Antoine et al., 2010; Becker et al., 2013; see Supplementary Information for details). It encompasses 278 cranio-mandibular, dental, and postcranial characters scored on 31 living and extinct perissodactyl species. Only six multistate characters were considered as non-additive (characters 66, 87, 95, 129, 177, and 263). All other multistate characters were treated as additive (see Character list in SI). Aside from outgroups (four perissodactyl species), the branching group (Antoine, 2002) consists of seven representatives of extinct rhinocerotid groups, including Teleoceratina (hippo-like rhinocerotines), Aceratheriini (hornless rhinocerotines), and an early offshoot of Elasmotheriinae (Subhyracodon occidentalis (Leidy, 1851)). The ingroup includes 20 terminals from the last 20 million years and consensually assigned to Rhinocerotina, i.e. the subtribe including all recent rhinoceroses and their extinct kin (see Supporting Information). 
Detailed information about the morpho-anatomical characters scored and terminal taxa included in the parsimony analysis are available in Supporting Information. The program PAUP 4.0a.158 (Swofford, 2002) was used for reconstructing the most parsimonious trees. Ages for nodes in the chronologically-constrained phylogenetic tree were obtained using the approach of Brusatte et al. (2008), as implemented in the paleotree package (Bapst et al., 2012 ) in R 4.0.3 (R core development team, 2020), with stratigraphical ranges as available in the NOW Database (Table S2; The NOW Community, 2020). As a prior, the first splitting event in the tree was set to $60 \mathrm{Ma}$ (mean value for Perissodactyla/Ceratomorpha; Foley et al., 2016) and the root of the tree was resolved using the APE package (Paradis et al., 2004). Six distinct historical biogeographical models were evaluated in BioGeoBEARS package in $R$ (Matzke, 2013; Massana et al., 2015) using eight basic spatial ranges, coinciding with the geographical areas of terminal taxa included in the phylogenetic and biogeographical analyses (Americas, Afro-Arabia, Europe + Mediterranean, Central Asia, South and Southeast Asia, Indonesia, Taiwan, Philippines). Historical spatial ranges were allowed to cover from 1 to 8 areas, which in turn resulted in 163 potential ancestral states.

Body mass was estimated using regressions based either on dental (Legendre, 1989; Fortelius \& Kappelman, 1993) and postcranial dimensions (Tsubamoto, 2012). Height at the shoulder was estimated by comparison with limb bones of recent rhinoceros species (Guérin, 1980) and further detailed in Supporting Information.

\section{RESULTS}

Phylogenetic ReLATIONSHIPS WITHIN RHINOCEROTIDAE

The first analysis, with 31 terminal taxa, recovered two equally most parsimonious trees (1321 steps each), with "Rhinoceros" Yanliang-Liucheng being sister taxon to either the ( $R$. philippinensis, $R$. sinensis hayasakai) clade or to the (Rhinoceros, Dicerorhinus) clade (Fig. S2). As i) we cannot discard the possibility that "Rhinoceros" Yanliang-Liucheng still be a chimaera (we were not able to observe directly the referred specimens) and ii) this issue falls beyond the scope of the present work, we have chosen to remove this terminal taxon from a second analysis, hence restricted to 30 terminal taxa (see $\mathrm{SI}$ ). In this second analysis, the heuristic search of PAUP 4.0a158 (Swofford, 2002), with ACCTRAN character-state optimization, retrieves a single most parsimonious tree (1315 steps; $\mathrm{Cl}=0.2821 ; \mathrm{Rl}=0.4858$ ), with exactly the same topology for all 30 taxa than in the previous analysis. We will focus on this topology detailed in the next paragraphs (Fig. 2).

Strictly speaking, monophyly of Rhinocerotidae is not retrieved, due both to the widelyundersampled Eocene-Oligocene rhinocerotid taxonomic diversity and the use of two earlydiverging rhinocerotids as outgroups in the present analysis (Trigonias osborni Lucas, 1900 and Ronzotherium filholi Osborn, 1900; Figure 2). Nevertheless, suprageneric relationships among Rhinocerotidae in the chronologically-constrained tree strictly conform to those of previous comprehensive analyses (Antoine, 2003; Becker et al., 2013), with a basal split between Rhinocerotinae and Elasmotheriinae (c $35.5 \mathrm{Mya}$ ), Aceratheriini and Rhinocerotini being sister taxa among Rhinocerotinae (both tribes split c 29.5 Mya), and Teleoceratina closely related to Rhinocerotina within Rhinocerotini and splitting c 27 Mya.

In the most parsimonious tree, two major clades diverge c 24 Mya among Rhinocerotina. The first one, strongly supported (Bremer Support [BS] > 5, 11 unambiguous synapomorphies [US]), coincides with Diceroti, an informal group of two-horned species from Eurasian and African landmasses with Dihoplus schleiermacheri (Kaup, 1832), "Dihoplus" pikermiensis Toula, 1906, Stephanorhinus etruscus (Falconer, 1868), 
"Stephanorhinus" megarhinus (de Christol, 1835), Coelodonta antiquitatis (Blumenbach, 1799), Ceratotherium neumayri (Osborn, 1900), Ceratotherium simum (Burchell, 1817), and Diceros bicornis (Linnaeus, 1758) diverging successively. As revealed by the high number of derived morpho-anatomical traits at each node (between 8 and 18), Diceroti have experienced fast phenotypical evolution (Figure S3), with staggered splits ranging the middle-late Miocene time interval (c 15-8 Mya; Figure 2). The second clade only gathers Eurasian species. In terms of taxonomical composition, it fully matches the Rhinoceroti. The Miocene clade Lartetotherium-Gaindatherium is the first offshoot, further having close affinities with living Asian rhinoceroses (see also Antoine, 2003; Antoine et al., 2010). It is sister group to a clade encompassing Dicerorhinus (with Dicerorhinus sumatrensis (Fischer, 1814) and Dicerorhinus fusuiensis Yan et al., 2014; see Supplementary Information for further details) and all other species historically assigned to Rhinoceros. Rhinoceroti are supported by six US, and a BS (2) lower than in all surrounding nodes. All representatives of Rhinoceroti are much more conservative phenotypically than Diceroti, as revealed by a twice as low number of apomorphies per node (ranging from 3 to 13; Figure S3). The resulting topology for extant rhinos places the African rhinoceroses (Diceros bicornis and Ceratotherium simum) as a sister clade to Asian rhinoceroses (Dicerorhinus sumatrensis, plus Rhinoceros unicornis Linnaeus, 1758 and Rhinoceros sondaicus Desmarest, 1822). This topology matches that of the "geographical hypothesis", supported by most recent molecular phylogenies (Yuan et al., 2014; Welker et al., 2017; Kosintsev et al., 2019). It differs from the "horn hypothesis" in the position of the two-horned Sumatran rhinoceros (Dicerorhinus sumatrensis), usually more closely related to two-horned African rhinoceroses than to the one-horned Asian Rhinoceros, as suggested by most morphology-based phylogenetic analyses (Antoine et al., 2010; Becker et al., 2013; Pandolfi et al., 2019), but also by a recent proteomic analysis encompassing living rhinoceroses and representatives of Coelodonta and Stephanorhinus (Cappellini et al., 2019). This original result - at least on morpho-anatomical grounds - probably results from the inclusion of a more comprehensive taxonomical sample among Rhinocerotina than in any former analyses. The current sample is likely to minimise topologic biases such as long-branch attraction, due to the very low relictual diversity of rhinoceroses today.

More strikingly, a very robust clade ( 6 US; BS $>5$ ) includes Rhinoceros philippinensis and $R$. sinensis hayasakai Otsuka \& Lin, 1984 (from the Early and Middle Pleistocene of Taiwan). This bispecific clade is well distinct from its sister taxon, the Dicerorhinus-Rhinoceros clade $(D R \mathrm{c})$. The $D R \mathrm{c}$ is much less supported (6 US; $\mathrm{BS}=2$ ), essentially on the basis of postcranial features (Table S1). All other representatives of Rhinoceros form a monophyletic group, with $R$. sondaicus as a first offshoot, and then $R$. sinensis Owen, 1870, $R$. unicornis, $R$. kendengindicus Dubois, 1908 and R. platyrhinus Falconer \& Cautley, 1846-1849branching successively (Figure 2). The two first nodes are strongly supported (13, then 8 US), mostly on postcranials; $\mathrm{BS}>5$ ). This topology further attests to the singularity of the Javan rhinoceros, Rhinoceros sondaicus, as it is excluded from a compound of large-bodied extinct species either closely related to or considered as junior synonyms of the Indian rhinoceros (Antoine, 2012; Pandolfi \& Maiorini, 2016), i.e., Rhinoceros sinensis, R. platyrhinus, and $R$. kendengindicus, the phylogenetic relationships of which are fully solved here (Figure 2; Supporting Information). To our knowledge, these terminals are here included for the first time into a formal phylogenetic analysis. As a result, and even if such a taxonomical revision falls beyond the scope of the current work, all of them would be valid species, mostly diagnosed by dental and, to a lesser extent, cranial features (Table S1). The chronologically- 
constrained analysis suggests that intrageneric splits for Rhinoceros would have occurred in Pliocene times, with multiple sub-coeval speciation events until the Early Pleistocene (c 3 Mya; Figure 2). Dicerorhinus as a clade includes Dicerorhinus sumatrensis (type species) and Dicerorhinus fusuiensis (formerly described as Rhinoceros fusuiensis, from the Early Pleistocene of South China and Myanmar (Yan et al., 2014; Tong \& Guérin, 2009); see Supporting Information), with a strong support ( 8 US; BS $=4$ ). This specific split is hypothesised to have occurred in the latest Miocene (c 6 Mya), i.e. long after the earliest unambiguous occurrence of Dicerorhinus in the lower Siwaliks of Pakistan (Heissig, 1972; Antoine et al., 2013; Antoine, in press).

According to the topology of the most parsimonious tree and in order to maintain Rhinoceros as a monophyletic genus (further diagnosed by 13 cranial and postcranial features; $\mathrm{SI}$ ), we propose to consider the clade formed by $R$. philippinensis and $R$. $s$. hayasakai as a distinct extinct genus among Rhinocerotina, here named Nesorhinus (see next section). This genus is characterised by six US (Figure 3; roots fully isolated on cheek teeth, crista absent on $\mathrm{P} 3$, protocone constriction always absent and posterior half of the ectoloph concave on M1-2, trigonid angular in occlusal view on lower cheek teeth, and posterior supraglenoid tubercle convex and salient on scapulae), among which four reversals (see Table S1). The type species is Nesorhinus philippinensis (Figure 3A-D, 3I, 3J), diagnosed by four dental autapomorphies (crochet always multiple on P2-4, metaloph transverse on $P 2$, external groove reaching the neck on lower cheek teeth and labial cingulum usually absent on lower premolars), the latter feature being a reversal. Nesorhinus hayasakai (Figure $3 \mathrm{E}-\mathrm{H}, 3 \mathrm{~K}$ ) possesses three dental autapomorphies (crochet always present on $\mathrm{P} 2-4$, lingual cingulum always absent on upper molars, and trigonid forming an acute dihedron in occlusal view on lower cheek teeth). The divergence between $N$. philippinensis and $N$. hayasakai is considered to have occurred by late Miocene times (c 7 Mya; Figure 2).

The taxonomic composition of Nesorhinus clade and the preferred timing of the corresponding intrageneric split offer a unique opportunity for discussing the biogeographical hypotheses that would explain the occurrence of rhinos in the Pleistocene deposits of the Philippine Archipelago.

Systematic PALAEOntology

\author{
Placentalia Owen, 1837 \\ Perissodactyla Owen 1848 \\ Rhinocerotidae Gray, 1821 \\ Rhinocerotina Gray, 1821 \\ Nesorhinus gen. nov.
}

(Figure 3)

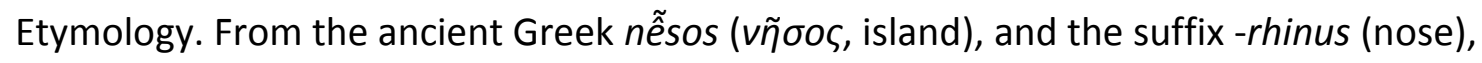
frequently used for designating rhinocerotid genera.

Type species. Nesorhinus philippinensis (von Koenigswald, 1956). See SI for further details.

Referred species. Nesorhinus hayasakai (Otsuka \& Lin, 1984).

Diagnosis. Medium-sized rhinocerotines, characterised by roots fully isolated on upper cheek teeth, a crochet usually present on $\mathrm{P} 2-4$, a crista absent on $\mathrm{P} 3$, a protocone constriction 
always absent and a posterior half of the ectoloph concave on M1-2, a trigonid angular in occlusal view on lower cheek teeth, and a posterior supraglenoid tubercle convex and salient on the scapula. Differing from representatives of both Dicerorhinus and Rhinoceros in having no cement on cheek teeth, a protocone joined to the ectoloph on P2, a proximal border of the third metatarsal sigmoid in anterior view, and intermediate reliefs high and sharp on metapodials. Distinct from Rhinoceros in possessing a protocone and a hypocone equally developed on P2 and in having no anterior trochlear notch on the astragalus. Further differing from Dicerorhinus in possessing a $\mathrm{V}$-shaped lingual opening of the posterior valley on lower premolars.

Geographic and stratigraphic range. Early and Middle Pleistocene of Luzon Island, Philippines, and of Taiwan Island (von Koenigswald, 1956; Ingicco et al., 2018; Otsuka \& Lin, 1984).

Description. See morpho-anatomical characters in Supporting Information.

Even if nasal or frontal bones are not recognised in the current hypodigm of $N$. philippinensis and N. hayasakai, Nesorhinus was most probably one-horned, i.e. with a nasal horn and no frontal horn, as inferred by the topology of the consensus tree: this is the ancestral condition in Rhinocerotina and Rhinoceroti, retained in Rhinoceros. According to the most parsimonious topologies, a frontal horn was acquired independently in Diceroti and Dicerorhinus sumatrensis (and perhaps also in D. fusuiensis) which is in full agreement with the most recent genomic phylogenies.

Body mass, as predicted from regressions on upper and lower teeth, but also on limb bones, with consistent results, is estimated at $998-1,670 \mathrm{~kg}$ for Nesorhinus (Table S5). Nesorhinus philippinensis, documented at Kalinga site by at least two individuals very similar in size, was the smallest and lightest species. Body weight ranged between 1,025-1,185 kg (mean: 1,103 $\mathrm{kg}$ ) based on dental predictors and 998-1,140 kg (mean: 1,069 kg) based on postcranial predictors, which falls between the known ranges of the Sumatran and Javan rhinos, the smallest of the extant rhinos. Nesorhinus hayasakai was somewhat heavier, with more variable weight estimates based on teeth (mean: 1,263 kg; range: 1,018-1,670 kg; Table S3), and a slightly heavier estimate based on radius (1,306 kg; Table S5). A shoulder height of c 1.23-1.30 $\mathrm{m}$ was estimated for $N$. philippinensis through comparison of forelimb dimensions with recent rhinos (mean: $1.26 \mathrm{~m}$ ). This estimate is similar to the smallest Javanese rhino individuals and to average Sumatran rhino individuals (Tables S6, S7). A marginally higher stature (c $1.31 \mathrm{~m}$ ) is inferred for N. hayasakai (see Tables S6, S7). Nevertheless, comparison of skeletal proportions shows that $N$. philippinensis was particularly slender-limbed, with the notable exception of the scapula and the metapodials. Its gracility indices are closely similar to those of the most gracile living rhinoceros, i.e., Dicerorhinus sumatrensis (Table S8;

Figures S5, S6). Within Nesorhinus, $N$. philippinensis was also much slenderer-limbed than $N$. hayasakai, which is further consistent with significantly lighter body mass estimates based on radius (998 vs 1,306 kg, respectively; Table S5). This discrepancy may be related either to inter-individual variability (e.g., sexual dimorphism - although it seems to be quite exaggerated for a rhinocerotine (Guérin, 1980)), or to a secondary adaptation to the unbalanced insular environment of the Philippines (Table S8) with respect to mainland assemblages. Strikingly, the scapula of $N$. philippinensis is neither particularly spatulate nor elongated. Its gracility equals that of Diceros bicornis and it is intermediate to the living 
Rhinoceros species, while Dicerorhinus sumatrensis has by far the most robust scapula (Table S8).

\section{DISCUSSION}

BIOGEOGRAPHICAL IMPLICATIONS FOR PAST DISPERSALS OF LAND MAMMALS TO THE PHILIPPINES AND THE INFLUENCE OF INSULARITY

The current phylogenetic analysis (Figure 2) benefits from a broad taxonomic sample, particularly comprehensive for Neogene and Pleistocene-Holocene Asian rhinos with wellconstrained spatiotemporal distribution. Moreover, the topology of the most parsimonious tree (Figure 2) can be interpreted in terms of historical biogeographical pattern and timing.

Parsimony, such as the least-cost pathway, in this case the shortest distance from mainland to an oceanic island, is repeatedly considered as the main argument when choosing one dispersion route over another, either passive or active (Field et al., 2007; Robles, 2013), although any longer overseas travel has been proven to be statistically far to be improbable (Antoine et al., 2008, 2010; Dennell et al., 2014). This is why Palawan Island has been consensually viewed until recently as the most probable main gate to the Philippines during the Pleistocene (Porr et al., 2012; Mijares, 2014). Some molecular phylogenies have further supported this hypothesis, although the timing of dispersal for most of them was pre-Pleistocene i.e., before the Philippines geological blocks acquired their present geographical distribution.

Per se, our results would suggest an island-hopping and/or sweepstake dispersal hypothesis for Nesorhinus, from the continental Indo-Malayan zoogeographic region (Figure 1) toward Luzon (N. philippinensis; known age: c 0.7 Myr) via Taiwan (N. hayasakai; considered range: 0.9-0.45 Myr). Accordingly, the current phylogenetic topology formally excludes any contribution from the well-documented Indonesian-sourced rhinos, assigned either to Dicerorhinus or to Rhinoceros from the Pleistocene of the Sundaic Region, such as $D$. sumatrensis, $R$. unicornis, $R$. sondaicus, or $R$. kendengindicus. Such a conclusion would therefore revive the north to south dispersal pattern to the Wallacean Islands as suggested by von Koenigswald (1956) and reject a dispersion from Borneo through Palawan, as one of the terminal phalanges of the Siva-Malayan and Sino-Malayan routes (Figure 1), a hypothesis favoured by all other scholars since then (Porr et al., 2012; Mijares, 2014), contra Morwood, 2014). Additionally, our phylogeny may further support one other Pleistocene route between India and Java (de Vos \& Long, 2001) being retrieved via the phylogenetic relationships of $R$. unicornis, $R$. kendengindicus, and $R$. platyrhinus (Figures 1,2 ).

In order to evaluate objectively these hypotheses, we have undertaken historical biogeographical analyses, using BioGeoBEARS package in R (Matzke, 2013; Massana et al., 2015). The model with the best Akaike Information Criterion (AIC) is BAYAREAlike + J (Table S3), in which the ancestral area of (Nesorhinus + (Rhinoceros + Dicerorhinus)) is mainland Asia and the geographical range of the common ancestor of Nesorhinus philippinensis and Nesorhinus hayasakai is either Taiwan or the Philippine Archipelago, with a subsequent dispersal to the Philippines or to Taiwan, respectively (Figure 4). Owing to the palaeogeographical context of the region as hypothesised for Neogene times (Hall, 2002), the first option (Taiwan toward Philippines) is much more likely to have occurred. Scenarios mostly varied whether founder speciation events were included or not, and the former option was always preferred in terms of AIC. Under that latter assumption, the geographical origin of Taiwanese and Philippine representatives of Nesorhinus is much more probably continental South East Asia and/or South Asia than the Sundaic Region (BAYAREAlike+J, 
DIVAlike+J, DEC+J). In the absence of founder speciation events, it was found that the ancestor might have had a more widespread distribution in South East Asia before speciating in allopatry, including the Sundaic Region (BAYAREAlike) or not (DEC, DIVAlike). Under the various scenarios examined, origination for Philippine and Taiwanese Nesorhinus would therefore be more likely in mainland Asia rather than the Sundaic region, even if the second option is not completely ruled out for one less-supported model (DIVAlike, DIVAlike + J, DEC, or DEC +J). Indeed, wide gaps in the fossil record for these lineages impedes backtracking precisely potential shifts in their past geographical distributions.

Reaching these oceanic islands would require some rafting on floating landmasses (Houle, 1998) for the smaller terrestrial species or some excellent swimming capabilities (Johnson, 1980) for the larger ones such as the rhinos and most certainly a combination of the two for most of the species (Lomolino, 2005). With the notable exception of somewhat sagittally-flattened metapodials, the osteological differences observed on N. philippinensis compared to the other species of the genus should not give rise to any functional interpretation. As observed in elephants (van der Geer et al., 2016) and hippos (Fisher et al., 2010), swimming abilities are not necessarily related to spatulate scapulae in large living ungulates, especially as the latter animals are bottom-walkers (Coughlin \& Fish, 2009). Extant Asian rhinos are all excellent swimmers, capable of crossing large river streams and marine corridors (Hoogerwerf, 1970; Konwar et al., 2009) and we see no reason why representatives of the new genus described here would have not acted the same. Most of Island Southeast Asia is surrounded by back-loop surface currents and the seas surrounding the Philippines are broadly flowing off the archipelago (Figure 1), a situation most likely also present during the glacial periods (Liu et al., 2016). This condition is presumably unfavourable for any successful accidental dispersion. However, winds have been proven to play a main role in sea surface drift of buoys (Houle, 1998; Gästgifvars et al., 2006). Prevailing Southeast Asian winds converge towards the equator and they are therefore mainly blowing to the South around and over the Philippine Islands (Liu et al., 2016). This condition would obviously be helpful for any dispersal in a north-south direction. Therefore, neither the direction of wind and sea surface current nor overseas distances can be used alone to support a specific dispersion route to the Philippines. Swimming over the Luzon Strait for the rhinos does not appear to be an impossible scenario when one considers that similarly-large animals have been observed to swim over tens of kilometres (Johnson, 1980) and that the greatest distance between two of the twelve islands separating Taiwan from Luzon was no more than $57 \mathrm{~km}$ during the most severe glacial periods with a sea level drop of ca. $120 \mathrm{~m}$ - a condition met during MIS 19 (Past Interglacials Working Group of PAGES, 2016). In good agreement with early occurrences of Gaindatherium and Dicerorhinus (Antoine et al., 2010; Heissig, 1972), the Nesorhinus-DRc split has supposedly occurred by early middle Miocene times (c 15 Mya; Figure 2; SI). Nesorhinus hayasakai ranges the c 0.90.45 Myr interval in Taiwan and N. philippinensis first occurs c 0.7 Mya in Luzon (see above). According to the paleotree model (Fig. 2; Brusatte et al., 2008), the split between $N$.

hayasakai and $N$. philippinensis has hypothetically occurred by latest Miocene times (c 7 Mya), a time interval further coinciding with a low sea level (Miller et al., 2020), which may have promoted such an oversea dispersal. Nevertheless, a Pleistocene overwater sweepstake dispersal toward Luzon cannot be fully discarded either for Nesorhinus (Figure 1). Whether other species dispersed to the Philippines through the northern route remains to be seen. We can nevertheless note that the absence of any contribution of Sundaic rhinos to the Philippine diversity of perissodactyls recalls what is observed for artiodactyls through 
the presence of the suid Celebochoerus in Luzon. This highly-island-endemic suid is also known from fossils from Sulawesi Island in the South but is notably absent in the well-known Javanese fossil record to the West (Ingicco et al., 2016). Unfortunately, the fragmentary condition of Celebochoerus specimens precludes any secure conclusions on the relationship between the two recognised species and the related discussion on its biogeographical implications, for instance whether this north to south dispersal can be extended further to the South from Luzon to Sulawesi. Indeed, the discovery of pre-Pleistocene large mammal fossils in the Philippine Archipelago (including Luzon), Taiwan, or in any Sundaic island would provide considerable insight into this long-lasting enigma.

\section{BODY MASS OF NESORHINUS AND ISLAND RULE}

The phylogenetically-constrained reconstruction of Nesorhinus hayasakai and $\mathrm{N}$. philippinensis clearly points to a decreased body mass and robustness in the oceanic island species in the Philippines with respect to mainland rhinoceros' species and its continental island sister species on Taiwan (Tables S8, S9; Figures S6, S7). It appears that $N$. philippinensis, although not dwarf but only of small stoutness like the Sumatran rhino, may follow in some instances the so-called island rule (Foster, 1964) when its relative postcranial robustness, with respect to its mainland and Taiwanese relatives. Notably because perissodactyls are frequently absent from unbalanced faunal communities on oceanic islands (van der Geer et al., 2010; Lomolino, 1985), it is to the best of our knowledge, the very first time that this order of mammals would be positively tested for the island rule. Following the results of our analysis, perissodactyls may add to the list of land mammals affected by this syndrome, which also includes proboscideans (van der Geer et al., 2016), artiodactyls ( van der Geer, 2005), rodents (McFarlane et al., 1998; Marivaux et al., 2020), carnivores (Lyras et al., 2010), and hominin primates (Bromham \& Cardillo, 2007).

\section{CONCLUSIONS}

This comprehensive morpho-anatomical phylogeny of Rhinocerotina, the group encompassing all living rhinoceroses and their extinct kin, allows for providing several calibration points for molecular studies among Rhinocerotidae, with a divergence between recent Asian and African rhinoceroses at c $24 \mathrm{Ma}$, further suggesting contrasting phenotypic evolutionary rates between both lineages. On morpho-anatomical grounds, it confirms the early split between Elasmotheriinae and Rhinocerotinae (c 35.5 Mya) as recently inferred from mitogenomic data (Kosintsev et al., 2019). Taxonomic affinities of a Pleistocene rhinoceros species represented by a partial skeleton found in $709 \pm 68$ ka-old archaeological deposits in Luzon Island, Philippines, lead to erect a new genus, Nesorhinus. This genus is an unsuspected Southeast Asian Pleistocene lineage closely related to Rhinoceros and Sumatran rhinos. From a biogeographical perspective, the current phylogenetic results strongly suggest an island-hopping overwater dispersal for Nesorhinus, from Asian mainland toward Luzon via Taiwan by latest Miocene or Early Pleistocene times. Furthermore, the extinct rhinocerotine Nesorhinus philippinensis from Luzon Island may be the first perissodactyl species positively supporting the "island rule", with a similar height at shoulder, but significantly decreased body weight and limb bone robustness with respect to its kin.

\section{ACKNOWLEDGEMENTS}

Jeremy Barns and Ana Labrador kindly provided support for this research as well as Gisela Concepcion and Marcelo de la Cruz Jr. The authors warmly thank Yuan Wang (Institute for 
Vertebrate Paleontology and Paleoanthropology) for pictures of Rhinoceros fusuiensis, Steven Zhang for discussion on rhinocerotine phylogeny, Christine Hertler for providing us access to the G.H.R. von Koenigswald archives curated at the Senckenberg Museum, and two anonymous reviewers of earlier versions of the manuscript for their expertise and constructive remarks. The Kalinga excavation project was funded by the French Department for Foreign Affairs (Project MARCHE, to TI), a National Geographic Global Exploration grant (GEFNE 129-14 with Alfred F. Pawlik), the French Centre National de la Recherche Scientifique (GDRi PalBiodivASE with Valéry Zeitoun), and Naturalis Biodiversity Center, the Netherlands. P.-O.A. received funding from the Embassy of France to the Philippines. The authors warmly thank Luca Pandolfi and two anonymous referees, as well as the associate editor Jake XXX, for their constructive and enthusiastic remarks on a previous version of the manuscript. This is ISEM-publication 2021-XXX.

\section{REFERENCES}

Antoine P-O. 2002. Phylogénie et évolution des Elasmotheriina (Mammalia, Rhinocerotidae). Paris.

Antoine P-O. 2003. Middle Miocene elasmotheriine Rhinocerotidae from China and Mongolia: taxonomic revision and phylogenetic relationships. Zoologica Scripta 32: 95118.

Antoine P-0. 2012. Pleistocene and Holocene rhinocerotids (Mammalia, Perissodactyla) from the Indochinese Peninsula. Comptes Rendus Palevol 11: 159-168.

Antoine P-O. in press. Rhinocerotids from the Siwalik faunal sequence. In: Badgley, C., D. Pilbeam \& M. Morgan (Eds.), At the Foot of the Himalayas: Paleontology and Ecosystem Dynamics of the Siwalik Record of Pakistan. Johns Hopkins University Press.

Antoine P-O, Karadenizli L, Saraç G, Sen S. 2008. A giant rhinocerotoid (Mammalia, Perissodactyla) from the Late Oligocene of north-central Anatolia (Turkey). Zoological Journal of the Linnean Society 152: 581-592.

Antoine P-O, Downing KF, Crochet J-Y, Duranthon F, Flynn LJ, Marivaux L, Métais G, Rajpar AR, Roohi G. 2010. A revision of Aceratherium blanfordi Lydekker, 1884 (Mammalia: Rhinocerotidae) from the Early Miocene of Pakistan: postcranials as a key: Miocene Rhinocerotids from Pakisatan. Zoological Journal of the Linnean Society 160: 139-194.

Antoine P-O, Métais G, Orliac MJ, Crochet J-Y, Flynn L, Marivaux L, Rajpar AR, Roohi G, Welcomme J-L. 2013. Mammalian Neogene biostratigraphy of the Sulaiman Province, Pakistan. In: Wang X.-m, L.J. Flynn \& M. Fortelius (Eds.), Fossil mammals of Asia: Neogene Biostratigraphy and Chronology, Columbia University Press, 400-422.

Bapst DW. 2012. paleotree: an R package for paleontological and phylogenetic analyses of evolution. Methods in Ecology and Evolution 3: 803-807.

Bautista AP. 1995. Fossil remains of rhinoceros from the Philippines. National Museum Papers 5: 1-9.

Becker D, Antoine P-O, Maridet O. 2013. A new genus of Rhinocerotidae (Mammalia, Perissodactyla) from the Oligocene of Europe. Journal of Systematic Palaeontology 11: 947-972.

Bellwood P. First Migrants: Ancient Migration in Global Perspective. John Wiley \& Sons.

Blumenbach JF. 1799. Handbuch der Naturgeschichte. Göttingen, Dieterich, xvi.

Braches F, Shutler Jr R. 1984. The Philippines and Pleistocene dispersal of mammals in Island Southeast Asia. Philippine Quarterly of Culture and Society 12: 106-115. 
Bromham L, Cardillo M. 2007. Primates follow the 'island rule': implications for interpreting Homo floresiensis. Biology Letters 3: 398-400.

Brown RM, Siler CD, Oliveros CH, Esselstyn JA, Diesmos AC, Hosner PA, Linkem CW, Barley AJ, Oaks JR, Sanguila MB, Welton $\amalg$, Blackburn DC, Moyle RG, Townsend Peterson A, Alcala AC. 2013. Evolutionary Processes of Diversification in a Model Island Archipelago. Annual Review of Ecology, Evolution, and Systematics 44: 411-435.

Brusatte SL, Benton MJ, Ruta M, Lloyd GT. 2008. Superiority, Competition, and Opportunism in the Evolutionary Radiation of Dinosaurs. Science 321:1485-9148.

Burchell WJ. 1817. Note sur une nouvelle espèce de Rhinocéros. Bulletin des sciences, Société philomatique, Paris: 96-97.

Cappellini E, Welker F, Pandolfi L, Ramos-Madrigal J, Samodova D, Rüther PL, Fotakis AK, Lyon D, Moreno-Mayar JV, Bukhsianidze M, Rakownikow Jersie-Christensen R, Mackie M, Ginolhac A, Ferring R, Tappen M, Palkopoulou E, Dickinson MR, Stafford TW, Chan YL, Götherström A, Nathan SKSS, Heintzman PD, Kapp JD, Kirillova I, Moodley Y, Agusti J, Kahlke RD, Kiladze G, Martínez-Navarro B, Liu S, Sandoval Velasco M, Sinding MHS, Kelstrup CD, Allentoft ME, Orlando L, Penkman K, Shapiro B, Rook L, Dalén L, Gilbert MTP, Olsen JV, Lordkipanidze D, Willerslev E. 2019. Early Pleistocene enamel proteome from Dmanisi resolves Stephanorhinus phylogeny. Nature 574: 103-107.

Coughlin BL, Fish FE. 2009. Hippopotamus Underwater Locomotion: Reduced-Gravity Movements for a Massive Mammal. Journal of Mammalogy 90: 675-679.

Dennell RW, Louys J, O'Regan HJ, Wilkinson DM. 2014. The origins and persistence of Homo floresiensis on Flores: biogeographical and ecological perspectives. Quaternary Science Reviews 96: 98-107.

Desmarest AG. 1822. Mammalogie ou description des espèces de mammifères (Vol. 2). Paris: chez Mme veuve Agasse (ed.).

Dubois E. 1908. Das geologische Alter der Kendeng-oder Trinil-fauna. Tijdschrift van het Koninklijk Nederlandsch Aardrijkskundig Genootschap 25: 1235-1270.

Esselstyn JA, Oliveros CH. 2010. Colonization of the Philippines from Taiwan: a multi-locus test of the biogeographic and phylogenetic relationships of isolated populations of shrews. Journal of Biogeography 37: 504-514.

Falconer H, Cautley PT. 1846-1849. Fauna antiqua sivalensis, being the fossil zoology of the Sewalik Hills, in the north of India. London: Falconer $\mathrm{H}$, ed.

Field JS, Petraglia MD, Lahr MM. 2007. The southern dispersal hypothesis and the South Asian archaeological record: Examination of dispersal routes through GIS analysis. Journal of Anthropological Archaeology 26: 88-108.

Fischer von Waldheim GF. 1814. Zoögnosia tabulis synopticis illustrate, in usum Paeselectionum Academiae Imperialis Medicochirurgae. Moscow: Nicolai Sergeidis Vsevolozsky, ed.

Fisher RE, Scott KM, Adrian B. 2010. Hind limb myology of the common hippopotamus, Hippopotamus amphibius (Artiodactyla: Hippopotamidae). Zoological Journal of the Linnean Society 158: 661-682.

Foley NM, Springer MS, Teeling EC. 2016. Mammal madness: is the mammal tree of life not yet resolved? Philosophical Transactions of the Royal Society B 371: 20150140.

Fortelius M, Kappelman J. 1993. The largest land mammal ever imagined. Zoological Journal of the Linnean Society 108: 85-101.

Foster JB. 1964. Evolution of Mammals on Islands. Nature 202: 234. 
Gästgifvars M, Lauri H, Sarkanen A, Myrberg K, Andrejev O, Ambjörn C. 2006. Modelling surface drifting of buoys during a rapidly-moving weather front in the Gulf of Finland, Baltic Sea. Merging Engineering and Science in Marine Environmental Model Applications 70: 567-576.

van der Geer AE. 2005. Island ruminants and the evolution of parallel functional structures. Quaternaire 2: 231-240.

van der Geer AAE, van den Bergh GD, Lyras GA. 2016. The effect of area and isolation on insular dwarf proboscideans. Journal of Biogeography 43: 1656-1666.

van der Geer AA, Lyras G, de Vos J, Dermitzakis M (Eds.). 2010. Evolution of island mammals: adaptation and extinction of placental mammals on islands. Hoboken, $\mathrm{NJ}$ : Wiley-Blackwell.

Gray JE. 1821. On the natural arrangements of vertebrose animals. London Medical Repository 15: 296-310.

Groves CP. 2001. Mammals of Sulawesi: where did they come from and when, and what happened to them when they got there? Faunal and floral migration and evolution in SEA Asia-Australasia. Lisse: I. Metcalfe, J.M.B. Smith, M. Morwood and I. Davidson, 333-342.

Guérin C. 1980. Les rhinocéros (Mammalia, Perissodactyla) du Miocène terminal au Pleistocène supérieur en Europe occidentale: comparaison avec les espèces actuelles. Villeurbanne: Département des sciences de la terre, Université Claude-Bernard Lyon 1.

Hall R. 2002. Cenozoic geological and plate tectonic evolution of SE Asia and the SW Pacific: computer-based reconstructions, model and animations. Journal of Asian Earth Sciences 20: $353-431$.

Hayasaka I. 1942. On the occurrence of mammalian remains in Taiwan. A preliminary summary. Taiwan Tigaku Kizi 13: 55-109.

Heaney LR. 1985. Zoogeographic evidence for Middle and Late Pleistocene land bridges to the Philippine Islands. Modern Quaternary Research in South-East Asia 9: 127-143.

Heissig K. 1972. Paläontologische und geologische Untersuchungen im Tertiär von Pakistan 5. Rhinocerotidae (Mammalia) aus den unteren und mittleren Siwalik-Schichten. Abhandlungen der Bayerischen Akademie der Wissenschaften, Mathematischnaturwissenschaftliche Klasse, München 152: 1-112.

Hoogerwerf A. 1970. Udjung Kulon, the land of the last Javan rhinoceros : with local and general data on the most important faunal species and their preservation in Indonesia. E.J. Brill, Leiden.

Hooijer DA. 1951. Pygmy elephant and giant tortoise. The Scientific Monthly 72: 3-8.

Hooijer DA. 1958. A. The Pleistocene Vertebrate Fauna of Celebes. Asian Perspectives 2: 7176.

Houle A. 1998. Floating Islands: A Mode of Long-Distance Dispersal for Small and MediumSized Terrestrial Vertebrates. Diversity and Distributions 4: 201-216.

Ingicco T, Bergh GD van den, Jago-on C, Bahain JJ, Chacón MG, Amano N, Forestier H, King $C$, Manalo $K$, Nomade $S$, Pereira $A$, Reyes $M C$, Sémah $A M$, Shao $Q$, Voinchet $P$, Falguères C, Albers PCH, Lising M, Lyras G, Yurnaldi D, Rochette P, Bautista A, Vos J de. 2018. Earliest known hominin activity in the Philippines by 709 thousand years ago. Nature 557: 233.

Ingicco T, van den Bergh G, de Vos J, Castro A, Amano N, Bautista A. 2016. A new species of Celebochoerus (Suidae, Mammalia) from the Philippines and the paleobiogeography of the genus Celebochoerus Hooijer, 1948. Geobios 49: 285-291. 
Ingicco T, Reyes MC, de Vos J, Belarmino M, Albers PCH, Lipardo I, Gallet X, Amano N, van den Bergh GD, Cosalan AD, Bautista A. 2020. Taphonomy and chronosequence of the 709 ka Kalinga site formation (Luzon Island, Philippines). Scientific Reports 10.

Johnson DL. 1980. Problems in the land vertebrate zoogeography of certain Islands and the swimming powers of elephants. Journal of Biogeography 7: 383-398.

Kaup JJ. 1832. Description d'Ossements fossiles de Mammifères inconnus jusqu'à présent, qui se trouvent au Musée grand-ducal de Darmstadt. Darmstadt: Heyer, J.G., ed.

von Koenigswald GHR. 1956. Fossil Mammals from the Philippines. National Research Council of the Philippines, University of the Philippines Diliman. Special reprint. Full text illustrations of paper 22 Proceedings of the Fourth Far-Eastern Prehistory Congress: 1-14.

Konwar P, Saikia MK, Saikia PK. 2009. Abundance of food plant species and food habits of Rhinoceros unicorns Linn. in Pobitora Wildlife Sanctuary, Assam, India. Journal of Threatened Taxa 1: 457-560.

Kosintsev P, Mitchell KJ, Devièse T, van der Plicht J, Kuitems M, Petrova E, Tikhonov A, Higham T, Comeskey D, Turney C, Cooper A, van Kolfschoten T, Stuart AJ, Lister AM. 2019. Evolution and extinction of the giant rhinoceros Elasmotherium sibiricum sheds light on late Quaternary megafaunal extinctions. Nature Ecology \& Evolution 3: 31-38.

Legendre S. 1989. Les communautés de mammifères du Paléogène (Eocène supérieur et Oligocène) d'Europe occidentale. Münchner geowissenschaftliche Abhandlungen. Reihe A, Geologie und Paläontologie 16: 1-110.

Leidy J. 1851. Remarks on Oreodon priscus and Rhinoceros occidentalis. Proceedings of the Academy of Natural Sciences of Philadelphia 5: 276.

Leidy J. 1871. Report on the vertebrate fossils of the Tertiary formations of the West. Annals and Reports of the United States geological and geographic Survey, Hayden 2: 340-370.

von Linnaeus C. 1758. Systema Naturae per regna tria naturae, secundum classes, ordines, genera, species, cum characteribus, differentiis, synonymis, locis. Stockholm, 10th edn, Vol. 1: Regnum animale.

Liu Z, Zhao Y, Colin C, Stattegger K, Wiesner MG, Huh CA, Zhang Y, Li X, Sompongchaiyakul $P$, You CF, Huang CY, Liu JT, Siringan FP, Le KP, Sathiamurthy E, Hantoro WS, Liu J, Tuo S, Zhao S, Zhou S, He Z, Wang Y, Bunsomboonsakul S, Li Y. 2016. Source-to-sink transport processes of fluvial sediments in the South China Sea. Earth-Science Reviews 153: 238273.

Lomolino MV. 1985. Body Size of Mammals on Islands: The Island Rule Reexamined. The American Naturalist 125: 310-316.

Lomolino MV. 2005. Body size evolution in insular vertebrates: generality of the island rule. Journal of Biogeography 32: 1683-1699.

Lucas FA. 1900. A new rhinoceros, Trigonias osborni, from the Miocene of South Dakota. United States National Museum Proceedings 23: 221-224.

Lyras GA, Van Der Geer AAE, Rook L. 2010. Body size of insular carnivores: evidence from the fossil record: Body size of fossil insular carnivores. Journal of Biogeography 37: 10071021.

Marivaux L, Vélez-Juarbe J, Merzeraud G, Pujos F, Viñola López LW, Boivin M, SantosMercado H, Cruz EJ, Grajales A, Padilla J, Vélez-Rosado KI, Philippon M, Léticée J-L, Münch P, Antoine P-O. 2020. Early Oligocene chinchilloid caviomorphs from Puerto Rico and the initial rodent colonization of the West Indies. Proceedings of the Royal Society $B$ : Biological Sciences 287: 20192806. 
Massana KA, Beaulieu JM, Matzke NJ, O'Meara BC. 2015. Non-null Effects of the Null Range in Biogeographic Models: Exploring Parameter Estimation in the DEC Model. bioRxiv http://biorxiv.org/content/early/2015/09/16/026914

Matzke NJ. 2013. Probabilistic Historical Biogeography: New Models for Founder-Event Speciation, Imperfect Detection, and Fossils Allow Improved Accuracy and Model-Testing. Frontiers of Biogeography 5: 242-248.

McFarlane DA, MacPhee RDE, Ford DC. 1998. Body Size Variability and a Sangamonian Extinction Model for Amblyrhiza, a West Indian Megafaunal Rodent. Quaternary Research 50: 80-89.

Mijares ASB. 2014. Human emergence and adaptation to an island environment in the Philippine Paleolithic. Emergence and diversity of modern human behavior in Paleolithic Asia. Y. Kaifu, M. Izuho, T. Goebel, H. Sato, A. Ono, 171-181.

Miller KG, Browning JV, Schmelz WJ, Kopp RE, Mountain GS, Wright JD (2020). Cenozoic sea-level and cryospheric evolution from deep-sea geochemical and continental margin records. Science Advances 6: eaaz1346.

Morwood MJ. 2014. Faunal biogeography in Island Southeast Asia implications for Early Hominin and Modern Human dispersals. Southern Asia, Australia and the search for Human origins. 108-117.

Osborn HF. 1900. Phylogeny of Rhinoceroses of Europe. Memoirs of the American Museum of Natural History 13: 229-267.

Otsuka H, Lin CC. 1984. Fossil Rhinoceros from the T'ouk'oushan Group in Taiwan. Journal of Taiwan Museum 37: 1-35.

Owen R. 1837. On the structure of the brain in marsupial animals. Philosophical Transactions of the Royal Society of London 127: 87-96.

Owen R. 1848. The archetype and homologies of the vertebrate skeleton. London.

Owen R. 1870. On fossil remains of mammals found in China. Quarterly Journal of the Geological Society 26: 417-436.

Pandolfi L, Maiorino L. 2016. Reassessment of the largest Pleistocene rhinocerotine Rhinoceros platyrhinus (Mammalia, Rhinocerotidae) from the Upper Siwaliks (Siwalik Hills, India). Journal of Vertebrate Paleontology 36: e1071266.

Paradis E., Claude J, Strimmer K. 2004. APE: analyses of phylogenetics and evolution in R language. Bioinformatics 20: 289-290.

Past Interglacials Working Group of PAGES. 2016. Interglacials of the last 800,000 years: Interglacials of the Last 800,000 Years. Reviews of Geophysics 54: 162-219.

Porr M, Mijares ASB, Pawlik AF, Piper PJ, Padilla S. 2012. North of the Southern Arc - The Mindoro Archaeological Research Program: A summary of the 2010 and 2011 fieldwork activities. Australian Archaeology 75: 110-117.

R Core Team. 2020. R: A language and environment for statistical computing. R Foundation for Statistical Computing, Vienna, Austria. URL https://www.R-project.org/.

Robles E. 2013. Estimates of Quaternary Philippine coastlines, land bridges, submerged river systems and migration routes: A GRASS GIS approach. Hukay 18: 31-53.

Singham G, Othman AS, Lee CY. 2017. Phylogeography of the termite Macrotermes gilvus and insight into ancient dispersal corridors in Pleistocene Southeast Asia. PloS one 12: e0186690-e0186690.

Suraprasit K, Jaeger JJ, Chaimanee Y, Chavasseau O, Yamee C, Tian P, Panha S. 2016. The Middle Pleistocene vertebrate fauna from Khok Sung (Nakhon Ratchasima, Thailand): biochronological and paleobiogeographical implications. ZooKeys 613: 1-157. 
Swofford DL. 2002. PAUP*: phylogenetic analysis using parsimony (* and other methods).

de Terra H, Movius Jr HL, Colbert EH, Bequaert J. 1941. Research on early Man in Burma, with supplementary reports upon the Pleistocene vertebrates and mollusks of the region, and Pleistocene geology and early Man in Java. Transactions of the American Philosophical Society. new series 32: 263-464.

Rhinocerotidae) from the latest Miocene of Southern Italy. Historical Biology, 1-15.

The NOW Community. 2020. New and Old Worlds Database of Fossil Mammals (NOW). Licensed under CC BY 4.0. Retrieved Nov 23, 2020 from https://nowdatabase.org/now/database/. http://doi.org/10.5281/zenodo.4268068

Tong Hao-wen, Guérin C. 2009. Early Pleistocene Dicerorhinus sumatrensis remains from the Liucheng Gigantopithecus Cave, Guangxi, China. Geobios 42: 525-539.

Tsubamoto T. 2012. Estimating body mass from the astragalus in mammals. Acta Palaeontologica Polonica 59: 259-265.

de Vos J, Long VT. 2001. First settlements: relations between continental and insular Southeast Asia. Origine des peuplements et chronologie des cultures Paléolithiques dans le Sud-est Asiatique. Paris: Sémah F., C. Falguères, D. Grimaud-Hervé, A.-M. Sémah, 225249.

Welker F, Smith GM, Hutson JM, Kindler L, Garcia-Moreno A, Villaluenga A, Turner E, Gaudzinski-Windheuser S. 2017. Middle Pleistocene protein sequences from the rhinoceros genus Stephanorhinus and the phylogeny of extant and extinct Middle/Late Pleistocene Rhinocerotidae. PeerJ 5: e3033.

Yan Y, Wang Y, Jin C, Mead JI. 2014. New remains of Rhinoceros (Rhinocerotidae, Perissodactyla, Mammalia) associated with Gigantopithecus blacki from the Early Pleistocene Yanliang Cave, Fusui, South China. Quaternary International 354: 110-121.

Yuan J, Sheng G, Hou X, Shuang X, Yi J, Yang H, Lai X. 2014. Ancient DNA sequences from Coelodonta antiquitatis in China reveal its divergence and phylogeny. Science China Earth Sciences 57: 388-396. 


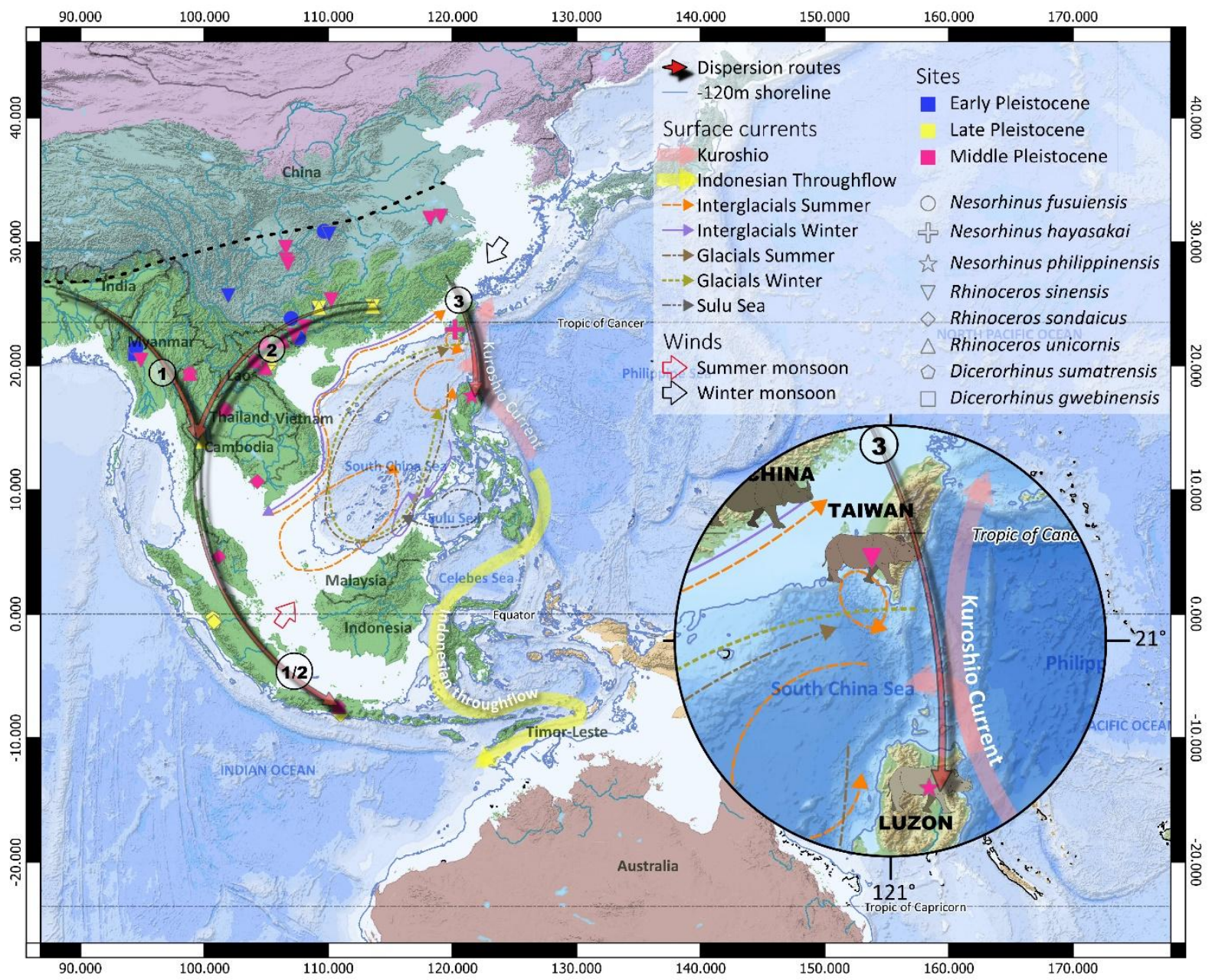

Figure 1. Physiogeographical map of Southeast Asia showing possible dispersal routes for Nesorhinus. Coloured lands account for the present zoogeographic regions. Palearctic in purple, Sino-Japanese in green-blue, Indo-Malayan in green, Australasian in orange and Australian in maroon (after Holt et al., 2013). The Palearctic-Oriental biogeographic boundary (dashed line) has been determined from several paleontological studies (see for instance Norton \& Braun, 2011). The different hypothesised dispersal paths are numbered, 1) for the Indo-Malayan route (Early and Middle Pleistocene), 2) for the Sino-Malayan route (Late Pleistocene), both ending in Java Island in the south (de Vos \& Long, 2001), and 3) for the Sino-Wallacean route following von Koenigswald (1956) and which we are reviving here. [full width suggested] 


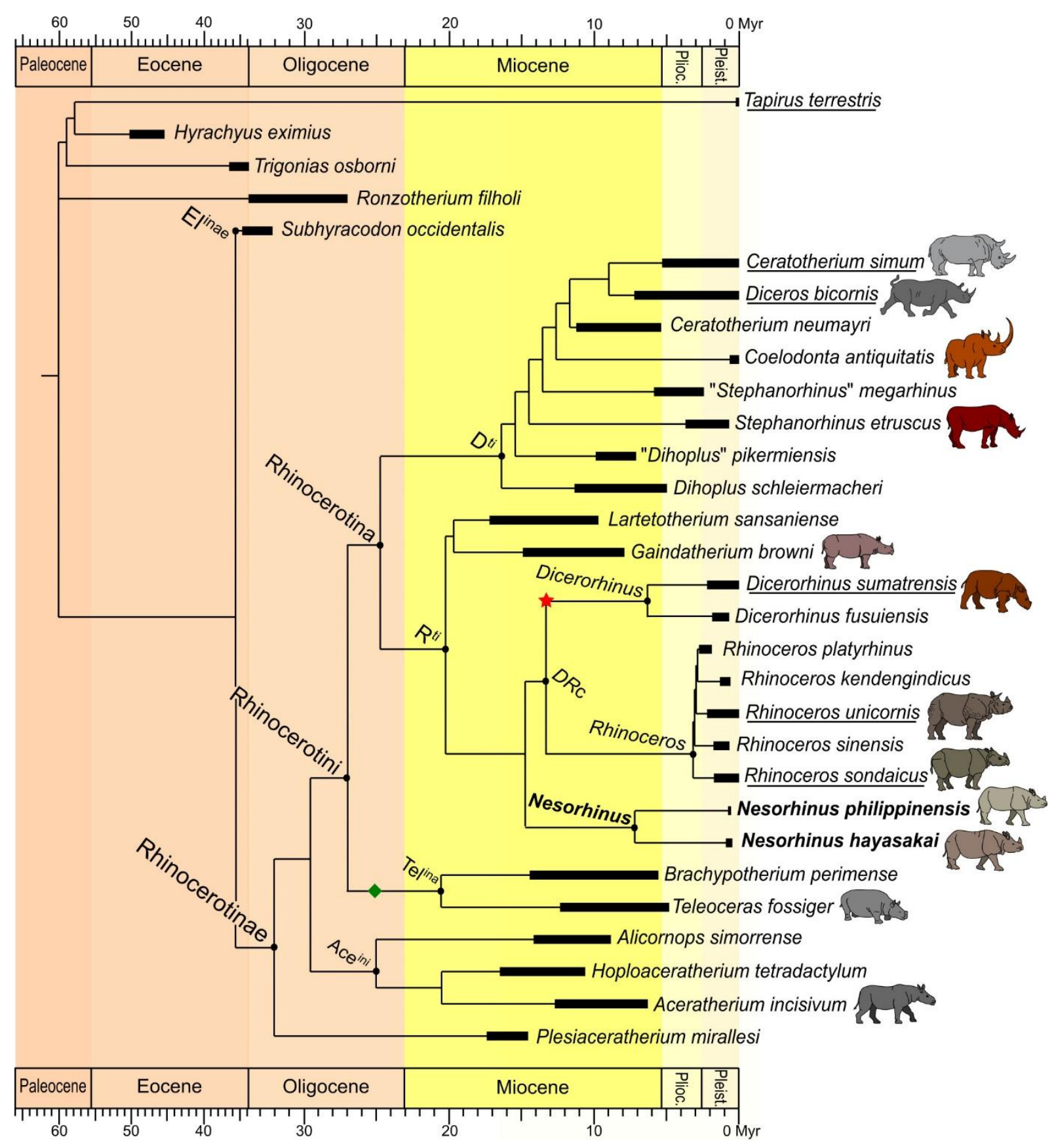

Figure 2. Phylogenetic tree of the Rhinocerotidae, built from 278 unweighted craniomandibular, dental, and postcranial characters scored in 30 ceratomorph species, and replaced in their stratigraphical context. Tapirus terrestris (Linnaeus, 1758), Hyrachyus eximius Leidy, 1871, Trigonias osborni, and Ronzotherium filholi were used as outgroups. Most parsimonious tree (length: 1315 steps; consistency index $=0.2821$; retention index $=$ 0.4858). Node ages were obtained using the approach of Brusatte et al. (2008), as implemented in the paleotree package (Bapst, 2012) in R 4.0.3 (R core development team, 2020), with the first splitting event set to $60 \mathrm{Ma}$. Red star and green diamond indicate the earliest occurrences of Dicerorhinus sensu stricto (13 Mya; Heissig, 1972; Antoine et al., 2013) and Teleoceratina (25 Mya; see Supporting Information). Ace ${ }^{\text {ini }}$, Aceratheriini; DRc, Dicerorhinus-Rhinoceros clade; $D^{\mathrm{ti}}$, Diceroti; El ${ }^{\text {inae }}$, Elasmotheriinae; $\mathrm{R}^{\mathrm{ti}}$, Rhinoceroti; Tel ${ }^{\text {ina }}$, Teleoceratina. Recent species' names are underlined. [Full width suggested] 


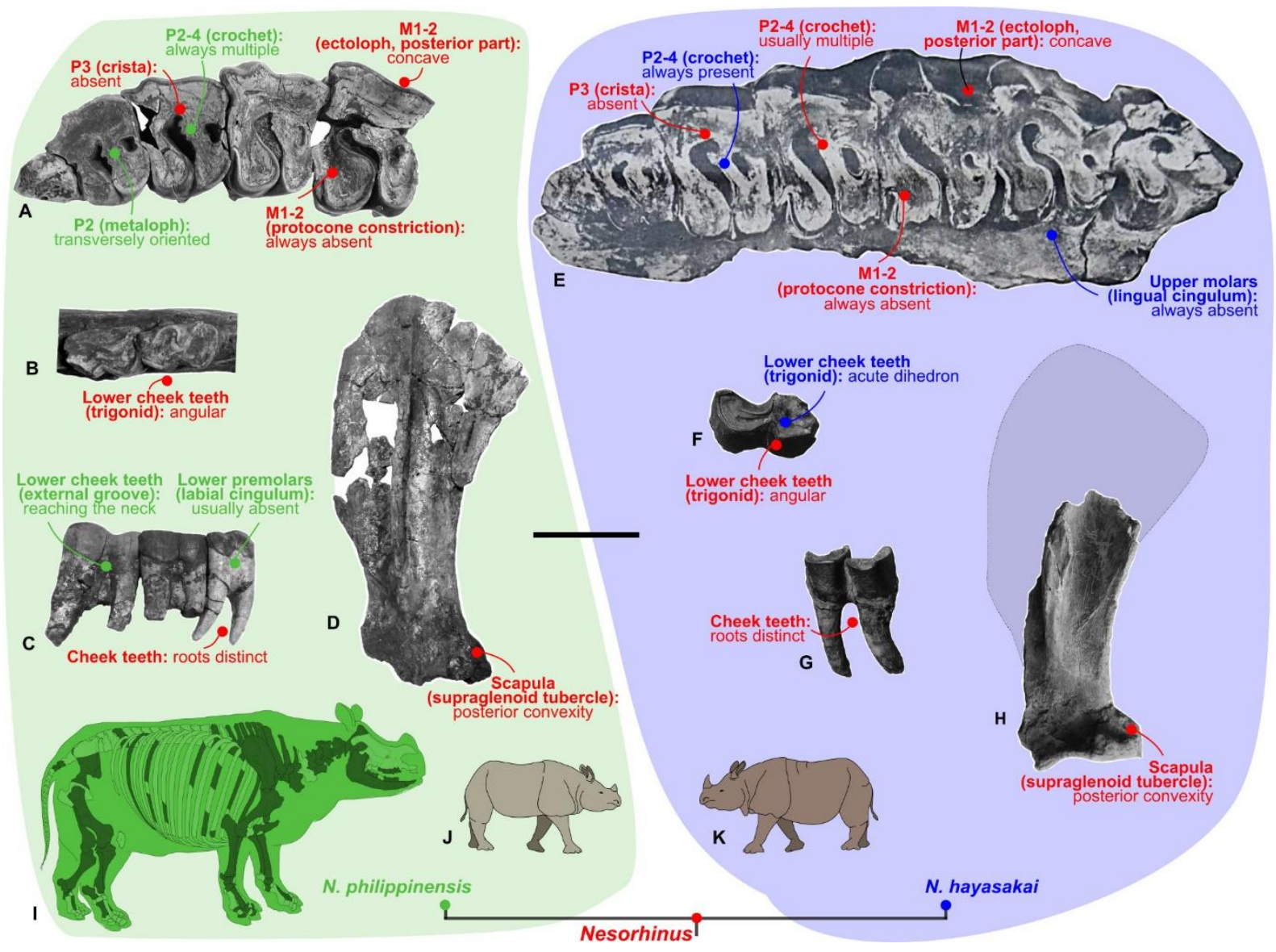

Figure 3. Dental and postcranial features characterising Nesorhinus n. g. in the phylogenetic framework as depicted in Figure 2. Red circles denote synapomorphies of Nesorhinus, whilst green and blue circles correspond to diagnostic characters (autapomorphies) of $N$. philippinensis and of N. hayasakai, respectively. Nesorhinus philippinensis: (a) left upper dental series (D1-M1) in occlusal view (II-2014-J1-294, 095, 409, 427); (b) left m2-3 in occlusal view (II-2014-J1-405); (c) right p3-m1 in labial view (II-2014-J1-451); (d) left scapula in lateral view (II-2014-J1-291). Nesorhinus hayasakai: (e) left upper dental series (D1-M3) in occlusal view (DGNTU-FV11b; modified from Hayasaka, 1942); (f) right m3 in occluso-labial view (HTR-55); $(g)$ left $m 3$ in labial view (HTR-91); (h); left fragmentary scapula (HTR-1). Completeness of the skeleton of $N$. philippinensis found at Kalinga (i): preserved elements appear in dark green. Tentative silhouettes of $N$ philippinensis $(j)$ and $N$. hayasakai $(k)$ are drawn at a same scale, with a shoulder height of $1.26 \mathrm{~m}$ for $N$. philippinensis. See Supporting Information for further details on body size. Scale bar, $5 \mathrm{~cm}(a-c, e-g)$ and $10 \mathrm{~cm}(d, h)$. [full width suggested] 


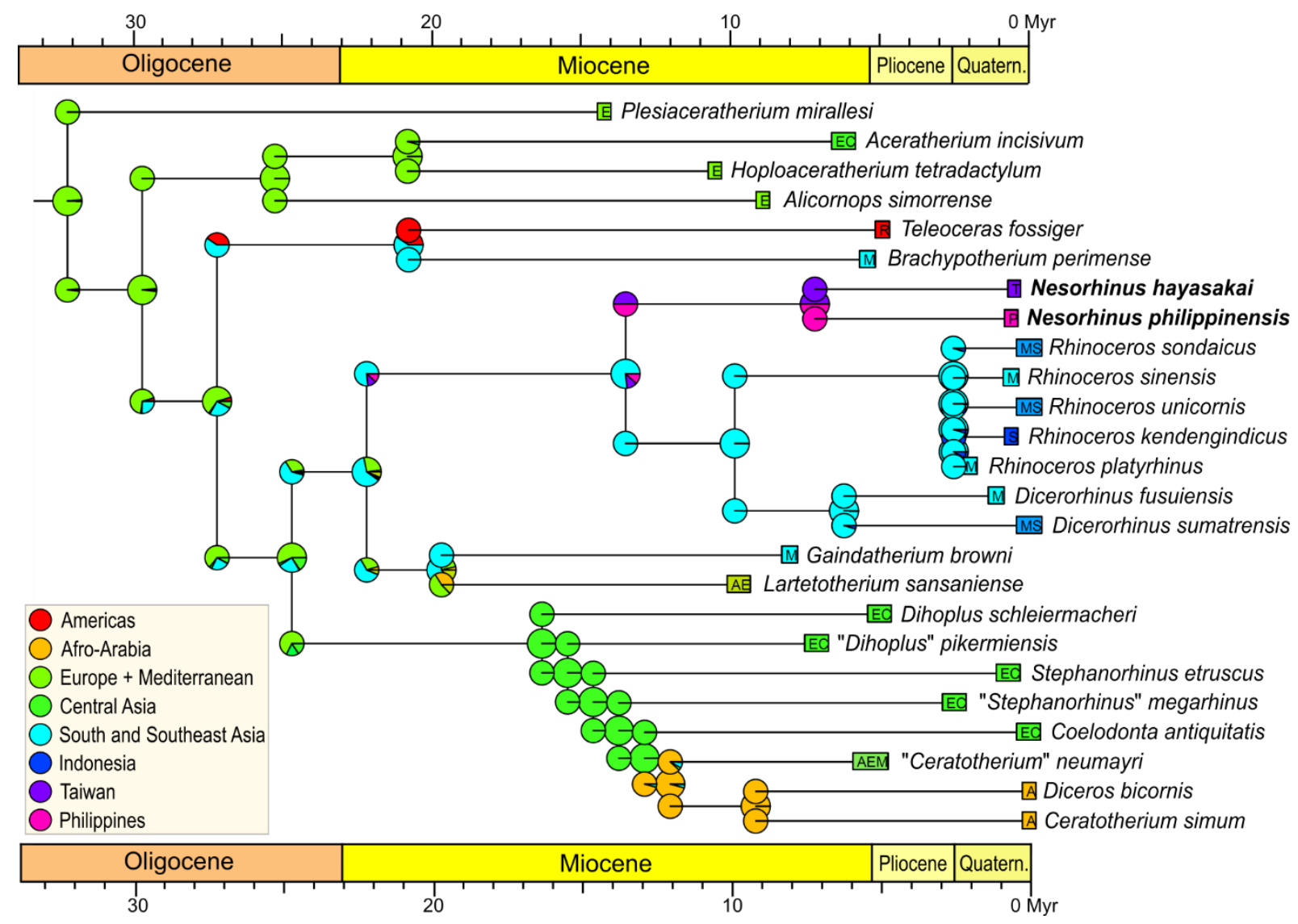

Figure 4. Ancestral biogeographical ranges of Rhinocerotinae, as calculated using BioGeoBEARS package in R (Matzke, 2013; Massana et al., 2015) and mapped on the phylogeny retrieved in Figure 3. Spatial ranges of all terminal taxa included in the phylogenetic and biogeographical analyses were split into eight domains, likely to coalesce: Americas [R], Afro-Arabia [A], Europe + Mediterranean [E], Central Asia [C], South and Southeast Asia [M], Indonesia [S], Taiwan [T], Philippines [P]. 